Dragana S. Malešević DOI: 10.19090/zop.2016.25.115-130

Ministarstvo prosvete, nauke i UDC: $371.3: 37.04$ tehnološkog razvoja, Originalni naučni rad

Školska uprava Novi Sad

Jovana J. Milutinović

Univerzitet u Novom Sadu,

Filozofski fakultet

\title{
SOCIJALNI I AFEKTIVNI EFEKTI PRIMENE PROGRAMA „KORAK PO KORAK"1
}

Apstrakt: Ključna ideja i opredeljenost za istraživanje proizlazi iz aktuelnosti potrebe za ispitivanjem efekata metodologija usmerenih na učenika. Cilj istraživanja jeste da se utvrde stavovi i mišljenja nastavnika, roditelja i učenika o socijalnim i afektivnim efektima primene elemenata Programa „Korak po korak” u Republici Srbiji, kao i da se ispitaju interpersonalni odnosi među učenicima, koji predstavljaju indikatore socijalnih i afektivnih efekata nastave. S obzirom na kompleksnost postavljenog istraživačkog cilja, rezultati i diskusija predstavljeni su kroz dve studije: prva studija odnosi se na procene nastavnika, roditelja i učenika osnovnoškolskog uzrasta o socijalnim i afektivnim efektima nastave, a uzorak obuhvata 1617 ispitanika. Druga studija sprovedena je radi utvrđivanja interpersonalnih odnosa među učenicima, a uzorak obuhvata 788 učenika osnovnoškolskog uzrasta. Primenjeni instrumenti su upitnik u formi Likertove skale o socijalnim i afektivnim efektima nastave i sociometrijski upitnik. Dobijeni rezultati pokazuju da nastavnici koji primenjuju elemente Programa „Korak po korak” imaju statistički značajno više vrednosti aritmatičke sredine na tvrdnjama koje se odnose na socijalne efekte u odnosu na nastavnike koji ovaj program ne primenjuju. Sociometrijskim ispitivanjem potvrđeno je da su pozitivni izbori učenika učestaliji, a negativni izbori manje učestali u odeljenjima u kojima se primenjuju elementi Programa „Korak po korak” u odnosu na odeljenja u kojima se elementi ovog programa ne primenjuju. Zaključuje se da dobijeni rezultati potvrđuju naučnu opravdanost primene metodologija usmerenih na dete, kao što je to Program „Korak po korak”. Implikacije ovog istraživanja mogu se posmatrati na makro nivou (republika, pokrajina, lokalna zajednica) i na mikro nivou (škola, odeljenja) obrazovanja u Srbiji.

Ključne reči: nastava usmerena na učenika, Program „Korak po Korak”, nastavnici, roditelji, učenici.

${ }^{1}$ Dragana Malešević, mpns.malesevic@eunet.rs, Jovana Milutinović, jovanajm@ff.uns. ac.rs 


\section{Uvod}

Strateški dokumentrazvoja obrazovanjau nasjesteStrategijarazvoja obrazovanja u Srbiji do 2020. godine (Službeni glasnik RS, 107/2012), kojom su utvrđeni svrha, ciljevi, pravci, instrumenti i mehanizmi razvoja sistema obrazovanja u Srbiji tokom narednih desetak godina. U ovom je dokumentu istaknuto opredeljenje Srbije za uključivanje u Evropsku uniju, što nameće potrebu da se strateški pravci razvoja obrazovanja u našoj zemlji usklade sa osnovnim tendencijama razvoja obrazovanja u Evropskoj uniji. Konstatovano je da u Srbiji učenici izlaze iz osnovne škole bez dovoljno razvijenih bazičnih kompetencija koje su im potrebne za nastavak školovanja i za bolje snalaženje u privatnom i javnom životu. Takođe, naglašeno je da su škole okrenute ka usko kognitivnom aspektu a ne ka celovitom razvoju ličnosti učenika. Izuzetno je mala zastupljenost savremenih oblika rada, pri čemu dominira predavačka nastava; malo se praktikuju aktivno učenje, istraživačke metode, individualizovana nastava i drugi pristupi i načini rada usmereni na učenika.

Značajno je to da se u Srbiji, radi prevazilaženja aktuelnog stanja u obrazovanju, primenjuju različiti programi i projekti, a jedan od njih jeste i Program „Korak po korak”, koji je dobio odobrenje i preporuku od strane Ministarstva prosvete i sporta Republike Srbije da se uvede kao pilot projekat od školske 2003/2004. godine u prvih pet model škola. Ovaj program predstavlja međunarodni obrazovni program kreiran od strane "Međunarodne Korak po korak asocijacije“ (International Step by Step Association - ISSA), koja je osnovana je 1999. godine radi potpomaganja procesa razvoja demokratije i promovisanja uključivanja porodice i zajednice u obrazovanje i vaspitanje učenika.

Program „Korak po korak” jeste savremena metodologija rada s decom i porodicom kreirana kao promišljen odgovor na korenite društvene promene, koje, pak, uslovljavaju promene u obrazovnom sistemu i menjaju ulogu obrazovno-vaspitnih institucija (Burke Walsh, 2003a, 2003b; Klaus \& Ghent, 2014). Program predstavlja holistički obrazovno-vaspitni pristup i polazi od stava da je razvoj svih dimenzija ličnosti - fizičkog, socijalnog, afektivnog i kognitivnog - jednako važan za sveukupni razvoj ličnosti deteta. Uvažavajući tradiciju i kulturne vrednosti zemlje u kojoj se implementira, metodologija „Korak po korak” orijentisana je na uvođenje i primenu kvalitetnog obrazovnog i vaspitnog delovanja usmerenog na dete (Milić, 2008). Teorijsko uporište ovog programa nalazi se u shvatanjima 
mnogih teoretičara, kao, na primer, Džona Djuija (John Dewey), Žana Pijažea (Jean Piaget), Lava Semjonoviča Vigotskog (Лев Семёнович Выготский), Haurda Gardnera (Howard Gardner) i Džeromi Brunera (Jerome Bruner). Socijalni konstukrivizam, koji naglašava središnu ulogu socijalnih interakcija u procesu učenja (Milutinović, 2005, 2011), takođe, predstavlja teorijsku osnovu nastavne prakse koja se sprovodi u okviru ovog programa.

Važno je to da su dosadašnja nezavisna ispitivanja pokazala da Program „Korak po korak” utiče na razvoj demokratskih ideja i vrednosti, te da daje veliku podršku celokupnom razvoju deteta (Klaus \& Ghent, 2014). Vrednovanje efekata ovog programa izvršeno je 2006. godine u Srbiji (Centar za evaluaciju, testiranje i istraživanje - CETI, 2006); rezultati pokazuju da njegova primena, u odnosu na uobičajeni način rada, dovodi do izvesnog, mada statistički neznačajnog, poboljšanja obrazovnih postignuća učenika. Rezultati istraživanja pokazuju i da su socijalni odnosi među učenicima i socijalna kohezija odeljenja poboljšani kao rezultat rada po Programu „Korak po korak”. Primena Programa značajno je uticala na unapređenje kvaliteta nastave, što se ispoljilo, između ostalog, kroz sledeće rezultate: učenici su razvili veoma pozitivan odnos prema novinama u nastavi; odnos između učitelja i učenika procenjen je kao veoma dobar i pozitivan; ostvarena je učestalija primena grupnog oblika rada i razvijeni su konstruktivni obrasci rada u grupi; značajno je unapređena participacija učenika u nastavi.

Različiti društveni, politički i ekonomski konteksti u Srbiji od 2002. godine do danas uslovili su i različite promene u našem obrazovnom sistemu, što je, pak, rezultiralo time da ovaj program nije uspeo u potpunosti da zaživi svoje metodologije, već samo u određenim elementima. Ključna ideja i opredeljenost za istraživanje ove teme proizlazi iz potrebe za ispitivanjem efekata primene metodologija usmerenih na dete, kao što je to Program „Korak po korak”, s namerom da se dobijeni rezultati primene u pedagoškoj praksi osnovnih škola. U radu se predstavlja i analizira segment šireg istraživanja efekata primene metodologije „Korak po korak”, konkretno onaj deo istraživanja koji se odnosi na socijalne i afektivne efekte njegove upotrebe. Problem predstavljenog dela istraživanja formulisan je pitanjem: da li postoje razlike u socijalnim i afektivnim efektima u odnosu na to da li se elementi Programa „Korak po korak” primenjuju ili ne primenjuju u odeljenjima razredne nastave osnovnih škola u Srbiji. 


\section{Metod}

Cilj istraživanja - utvrditi stavove i mišljenja nastavnika, roditelja i učenika o socijalnim i afektivnim efektima primene elemenata Programa „Korak po korak” u Republici Srbiji, kao i ispitati interpersonalne odnose među učenicima, koji predstavljaju indikatore socijalnih i afektivnih efekata nastave. Ovako postavljen cilj istraživanja operacionalizovan je kroz istraživačke zadatke koji se odnose na ispitivanje stavova nastavnika, stavova roditelja i mišljenja učenika o socijalnim i afektivnim efektima nastave u odeljenjima u kojima se primenjuju elementi Programa „Korak po korak", kao i stavova nastavnika, roditelja i učenika o socijalnim i afektivnim efektima nastave u odeljenjima u kojima se elementi ovog programa ne primenjuju. Poseban zadatak odnosi se na ispitivanje interpersonalnih odnosa učenika u odeljenjima u kojima se primenjuju elementi Programa „Korak po korak” i interpersonalnih odnosa učenika u odeljenjima u kojima se ne primenjuju elementi ovog programa.

Varijable $i$ instrumenti - U svojstvu nezavisne varijable pojavljuje se primena elemenata Programa „Korak po korak”. Kao zavisne varijable određene su procene nastavnika, roditelja i učenika o socijalnom i afektivnom domenu pedagoških efekata nastave, te socijalni i afektivni efekti nastave.

$\mathrm{U}$ ispitivanju procene socijalnih $\mathrm{i}$ afektivnih efekata Programa „Korak po korak” primenjen je instrument koji je konstruisan baš za potrebe ovog istraživanja. Svaki upitnik za ispitivanje procene nastavnike, roditelja i učenika, od ukupno dvadeset sedam ajtema, sadrži osamnaest ajtema za socijalne i afektivne efekte i konstruisan je u formi Likertove skale. Socijalni i afektivni efekti određivani su na osnovu ISSA pedagoških standarda kompetencija nastavnika. Odabrani efekti izraženi su u formi tvrdnji čiju su prisutnost nastavnici, roditelji i učenici procenjivali na skali od 1 do 4 (1 - uvek; 2 - često; 3 - ponekad; 4 - nikad). U cilju realizacije postavljenog istraživačkog zadatka koji se odnosi na ispitivanje interpersonalnih odnosa među učenicima primenjen je sociometrijski upitnik, koji se sastoji od četiri pitanja koja se tiču privlačenja (pozitivni odnosi) i odbijanja (negativni odnosi) između učenika i uzroka pozitivnih odnosa.

Uzorak ispitanika - Kada je reč o ispitivanju stavova i mišljenja nastavnika, roditelja i učenika o socijalnim i afektivnim efektima primene elemenata Programa „Korak po korak”, uzorak istraživanja čini 1617 ispitanika (nastavnici, roditelji i učenici) iz Novog Sada, Selenče, Pivnica, Niša i Beograda. Ukupan uzorak čine dve grupe podeljene prema nezavisnoj 
varijabli. Prvu grupu predstavljaju nastavnici, roditelji i učenici iz odeljenja osnovnih škola u kojima se primenjuju elementi Programa „Korak po korak", a drugu nastavnici, roditelji i učenici iz odeljenja osnovnih škola u kojima se ne primenjuju elementiovog programa. Struktura uzorka, te njegova ujednačenost u pogledu relevantne varijable, vidljiva je iz Tabele 1.

Tabela 1. Struktura uzorka u odnosu na primenu elemenata Programa

\begin{tabular}{lllll}
\multicolumn{5}{c}{ „Korak po korak” } \\
\hline Grupa & $\begin{array}{l}\text { Broj } \\
\text { nastavnika }\end{array}$ & $\begin{array}{l}\text { Broj } \\
\text { učenika }\end{array}$ & $\begin{array}{l}\text { Broj } \\
\text { roditelja }\end{array}$ & Ukupno \\
\hline Prva grupa & 21 & 403 & 373 & 797 \\
Druga grupa & 22 & 404 & 394 & 820 \\
Ukupno & 43 & 807 & 767 & 1617 \\
\hline
\end{tabular}

Uzorak istraživanja - $\mathrm{u}$ delu ispitivanja interpersonalnih odnosa među učenicima - čini 788 učenika osam osnovnih škola iz Novog Sada, Selenče, Niša i Beograda. Ukupan uzorak su dve grupe podeljene prema nezavisnoj varijabli. Prvu grupu čine učenici iz odeljenja u kojima se primenjuju elementi Programa „Korak po korak”, a drugu učenici iz odeljenja u kojima se ne primenjuju elementi ovog programa. Struktura uzorka, te njegova ujednačenost u pogledu relevantne varijable, vidljiva je iz Tabele 2 .

Tabela 2. Struktura uzorka učenika u odnosu na primenu elemenata Programa ,Korak po korak” i po školama

\begin{tabular}{llll}
\hline Prva grupa & \multicolumn{2}{c}{ Druga grupa } \\
\hline Škola & $\begin{array}{l}\text { Broj } \\
\text { učenika }\end{array}$ & Škola & $\begin{array}{l}\text { Broj } \\
\text { učenika }\end{array}$ \\
\hline $\begin{array}{l}\text { OŠ „,Sonja Marinković”, Novi } \\
\text { Sad }\end{array}$ & 130 & $\begin{array}{l}\text { OŠ „Vasa Stajić”, Novi } \\
\text { Sad }\end{array}$ & 130 \\
OŠ „,Jan Kolar”, Selenča & 90 & OŠ „15. oktobar”, Pivnice & 75 \\
OŠ „,Sreten Mladenović Mika”, & 112 & $\begin{array}{l}\text { OŠ „Ratko Vukićević”, } \\
\text { Niš }\end{array}$ & 96 \\
Niš & & OŠ „Pavle Savić”, & 90 \\
OŠ „Despot Stefan Lazerević”, & 65 & Beograd & 391 \\
Beograd & 397 & Ukupno & 39 \\
Ukupno & & & \\
\hline
\end{tabular}




\section{Rezultati i diskusija}

S obzirom na kompleksnost postavljenog istraživačkog cilja, rezultati i diskusija predstavljeni su kroz dve studije: prva studija odnosi se na procene socijalnih $i$ afektivnih efekata nastave, a druga na interpersonalne odnose kao indikatore socijalnih i afektivnih efekata nastave.

Socijalni i afektivni efekti nastave - procene nastavnika, učenika $i$ roditelja - Prva studija sprovedena je kako bi se ispitali stavovi i mišljenja nastavnika, roditelja i učenika o socijalnim i afektivnim efektima primene elemenata Programa „Korak po korak”. Podela na socijalne i afektivne efekte izvršena je za potrebe istraživanja, pri čemu je važno da u praksi postoji njihova velika međuzavisnost i povezanost. U radu je ispitivano da li postoje statistički značajne razlike na ukupnom skoru za procenu socijalnih efekata, a potom i na ukupnom skoru za procenu afektivnih. Nakon toga utvrđivano je na kojim socijalnim i afektivnim efektima postoje statistički značajne razlike u proceni prve i druge grupe ispitanika. Zbirni rezultati za procene socijalnih efekata nastavnika, roditelja i učenika prikazani su u Tabeli 3 .

Tabela 3. Zbirni rezultati za socijalne efekte - procene nastavnika, roditelja i učenika

\begin{tabular}{lllllll}
\hline Grupa & & $\mathrm{N}$ & $\mathrm{AS}$ & $\mathrm{SD}$ & $\mathrm{t}$ & $\mathrm{p}$ \\
\hline \multirow{2}{*}{ Nastavnici } & Prva grupa & 21 & 23.00 & 2.83 & \multirow{2}{*}{$\mathbf{2 . 3 1}$} & \multirow{2}{*}{$\mathbf{0 . 0 3}$} \\
& Druga grupa & 17 & 21.18 & 1.78 & & \\
\hline \multirow{2}{*}{ Roditelji } & Prva grupa & 336 & 22.43 & 3.56 & \multirow{2}{*}{0.78} & \multirow{2}{*}{0.44} \\
& Druga grupa & 372 & 22.23 & 3.30 & & \\
\hline \multirow{2}{*}{ Učenici } & Prva grupa & 377 & 21.81 & 3.38 & \multirow{2}{*}{1.75} & \multirow{2}{*}{0.09} \\
& Druga grupa & 365 & 21.37 & 3.49 & & \\
\hline
\end{tabular}

Napomena: N - veličina uzorka; AS - aritmetička sredina; SD standardna devijacija; $\mathrm{p}$ - nivo značajnosti; prva grupa: nastavnici, roditelji i učenici u odeljenjima u kojima se primenjuju elementi Programa „Korak po korak"; druga grupa: nastavnici, roditelji i učenici u odeljenjima u kojima se ne primenjuju elementi Programa „Korak po korak”.

Statistički značajne razlike dobijene su u aritmetičkim sredina 
na ukupnom skoru procene nastavnika o socijalnim efektima, gde višu aritmetičku sredinu imaju nastavnici koji primenjuju elemente Programa „Korak po korak" $(\mathrm{t}=2,31 ; \mathrm{p}<0,05)$ u odnosu na nastavnike koji ove elemente ne primenjuju. Statistički značajne razlike nisu dobijene u aritmetičkim sredina na ukupnom skoru procene roditelja i učenika o socijalnim efektima nastave.

Daljom analizom podataka za socijalne efekte utvrđivano je da li postoje statistički značajne razlike na pojedinačnim tvrdnjama. Broj tvrdnji za koje je uočena statistička značajnost razlika u korist nastavnika, roditelja i učenika uključenih u primenu elemenata programa „Korak po korak” (prva grupa) ukupno je devet. Broj tvrdnji za koje je nađena statistička značajnost razlika na pojedinačnim tvrdnjama za socijalne efekte u korist nastavnika, roditelja i učenika koji nisu uključeni u primenu elemenata ovog programa (druga grupa) ukupno je četiri. Statistički značajna razlika na pojedinačnim socijalnim efektima dobijena je u proceni nastavnika za tvrdnju koja se odnosi na sposobnost učenika da rade u timu - Sposobni su da rade $u$ timu $(\mathrm{t}=2,19 ; \mathrm{p}<0,05)$, pri čemu višu aritmetičku sredinu imaju nastavnici iz prve grupe. Analiza procene socijalnih efekata pokazuje da se prosečne vrednosti procene roditelja razlikuju u tri tvrdnje. Za tvrdnje Radi u timu (zajednički plakati, projekti i dr. u školi i kod kuće) $(\mathrm{t}=2,34 ; \mathrm{p}<0,05)$ i Moje dete u školi učestvuje u donošenju odluka $(\mathrm{t}=2,60 ; \mathrm{p}<0,05)$ višu prosečnu vrednost imaju roditelji iz prve grupe, a za tvrdnju Tolerantno je na razlike $(\mathrm{t}=2,20 ; \mathrm{p}<0,05)$ višu prosečnu vrednost imaju roditelji iz druge grupe. Razlike u proceni pojedinačnih socijalnih efekata uočene su na tvrdnjama učenika Ponašam se po pravilima ponašanja $(\mathrm{t}=2,04 ; \mathrm{p}<0,05)$, Slobodno kažem svoje mišljenje $(\mathrm{t}=2,80 ; \mathrm{p}<0,01)$ i $U$ školi učestvujem $u$ donošenju odluka $(\mathrm{t}=3,21 ; \mathrm{p}<0,01)$. Prosečna ocena za prvu tvrdnju viša je kod učenika iz druge grupe, dok je za druge dve tvrdnje aritmetička sredina viša kod učenika iz prve grupe.

Značajno je to da je saglasnost u proceni nastavnika i roditelja iz prve grupe potvrđena za socijalni efekat ISSA pedagoških standarda iz oblasti Interakcija - standard 1.2, pokazatelj 1: Učitelj podstiče interakcije među učenicima koje pospešuju njihov socijalni razvoj, postizanje zajedničkog razumevanja, uzajamnu podršku i osećaj zajedništva da bi im pomogao da dostignu ciljeve učenja i razvoja. Prosečne vrednosti procene nastavnika i roditelja iz prve grupe za tvrdnju Sposobni su da rade u timu značajno su više od prosečnih vrednosti procene nastavnika i roditelja iz druge grupe. Objašnjenje viših prosečnih vrednosti nalazi se verovatno u 
činjenici da kooperativno učenje, kao svakodnevni rad učenika u centrima aktivnosti u kojima se radi u timovima od četiri ili pet učenika, predstavlja jednu od osnovnih karakteristika Programa „Korak po korak”.

Kada je reč o socijalnom efektu ISSA pedagoških standarda iz oblasti Interakcija - standard 1.2, pokazatelj 3: Učitelj promoviše demokratske vrednosti ohrabrujući svakog učenika da na primeren način izrazi vlastito mišljenje $i$ učestvuje $u$ donošenju odluka, utvrđeno je da su prosečne vrednosti procene učenika i roditelja iz prve grupe za tvrdnju $U$ školi učestvujem u donošenju odluka/Moje dete u školi učestvuje u donošenju odluka značajno više od prosečnih vrednosti procene učenika i roditelja iz druge grupe. Više prosečne vrednosti procene učenika i roditelja iz prve grupe mogle bi biti posledica načina rada u okviru Programu „Korak po korak", te njegove zasnovanosti na demokratskim vrednostima. Ovde je reč je o specifičnoj metodologiji rada s decom: nastavnici iz prve grupe organizuju aktivnosti koje učenike često stavljaju u situacije donošenja odluka, te kreiraju kontekst u kojem se neguje samostalno i nezavisno mišljenje. Sve se ovo može dovesti u vezu sa prosečnom vrednošću dobijenom za tvrdnju Slobodno kažem svoje mišljenje. Naime, u okviru ove stavke učenici koji se školuju po elementima Programa „Korak po korak" imaju značajno više prosečne vrednosti u odnosu na učenike koji se ne školuju po elementima ovog programa. Ovakav rezultat verovatno proizlazi iz metodologije Programa „Korak po korak”, koji pretostavlja kreiranje atmosfere međusobnog uvažavanja i slobodnog izražavanja mišljenja.

Međutim, za oblast Inkluzija, različitost i demokratske vrednosti - standard 3.3, pokazatelj 1: Učitelj kod učenika podstiče razumevanje $i$ uvažavanje različitih stavova i mišljenja, te im pomaže u razvoju veština potrebnih za primereno izražavanje vlastitih stavova, analiza prosečnih vrednosti procene za tvrdnju Tolerantno je na razlike pokazuje da su prosečne vrednosti procene roditelja čija deca ne pohađaju odeljenja $u$ kojima se primenjuju elementi Programa „Korak po korak” (druga grupa) više u odnosu na prosečne vrednosti procene roditelja čija se deca školuju u odeljenjima u kojima se primenjuju elementi ovog programa. Postoji mogućnost da je dobijena razlika u proceni roditelja uslovljena uzorkom, to jest psiho-fizičkim karakteristikama učenika i socijalnim kontekstom.

Kada je reč o afektivnim efektima, zbirni rezultati za procene nastavnika, roditelja i učenika prikazani su u Tabeli 4. 
Tabela 4. Zbirni rezultati za afektivne efekte - procene nastavnika, roditelja i učenika

\begin{tabular}{lllllll}
\hline Grupa & & & AS & SD & $\mathrm{t}$ & $\mathrm{p}$ \\
\hline Nastavnici & Prva grupa & 21 & 21.90 & 3.06 & \multirow{2}{*}{0.65} & \multirow{2}{*}{0.52} \\
& Druga grupa & 21 & 21.38 & 2.01 & & \\
\hline \multirow{2}{*}{ Roditelji } & Prva grupa & 342 & 21.60 & 4.13 & & \multirow{2}{*}{0.15} \\
& Druga grupa & 383 & 22.01 & 3.47 & & \\
\hline Učenici & Prva grupa & 380 & 22.31 & 4.02 & \multirow{2}{*}{0.67} & 0.50 \\
& Druga grupa & 364 & 22.12 & 3.58 & & \\
\hline
\end{tabular}

Napomena: N - veličina uzorka; AS - aritmetička sredina; SD standardna devijacija; $\mathrm{p}$ - nivo značajnosti; prva grupa: nastavnici, roditelji i učenici u odeljenjima u kojima se primenjuju elementi Programa „Korak po korak"; druga grupa: nastavnici, roditelji i učenici u odeljenjima u kojima se ne primenjuju elementi Programa „Korak po korak”.

$\mathrm{Na}$ osnovu prikazanih rezultata t-testa na nezavisnim uzorcima za ukupan skor procene afektivnih efekata, može se zaključiti da razlika između nastavnika, roditelja i učenika u odeljenjima u kojima se primenjuju elementi Programa „Korak po korak” i nastavnika, roditelja i učenika $\mathrm{u}$ odeljenjima u kojima se ne primenjuju elementi ovog programa nije statistički značajna. Daljom analizom podataka utvrđivano je da li postoje statistički značajne razlike na pojedinačnim tvrdnjama za afektivne efekte.

Analiza pokazuje da su razlike statistički značajne samo kada je reč o proceni nastavnika da učenici Vole da se međusobno pomažu $u$ učenju $i$ radu $(\mathrm{t}=2,18 ; \mathrm{p}<0,03)$. Prosečna vrednost procene roditelja za afektivne efekte razlikuje se kada je reč o tvrdnjama Zainteresovano je za učestvovanje u raznim aktivnostima izvan škole $(\mathrm{t}=1,75 ; \mathrm{p}<0,05)$, gde višu vrednost aritmetičke sredine imaju roditelji iz druge grupe i Moje dete prepoznaje emocije kod sebe $i$ drugih $(\mathrm{t}=2,60 ; \mathrm{p}<0,01)$, gde višu vrednost aritmetičke sredine imaju roditelji iz prve grupe. Dalje je utvrđeno da na tvrdnjama Volim da istražujem $i$ eksperimentišem $(\mathrm{t}=3,55 ; \mathrm{p}<0,01)$ i Prepoznajem emocije kod sebe $i$ drugih $(\mathrm{t}=2,93 ; \mathrm{p}<0,01)$ statistički značajno višu vrednost aritmetičke sredine imaju učenici koji pohađaju nastavu s elementima Programa „Korak po korak”. S druge strane, na tvrdnji Ja osećam da pripadam svom odeljenju i tu mi je dobro učenici 
koji ne pohađaju nastavu u kojoj se primenjuju elementi Programa „Korak po korak" imaju značajno viši prosečan skor $(\mathrm{t}=1,86 ; \mathrm{p}<0,05)$.

U proceni afektivnog efekta Vole da se međusobno pomažu u učenju $i$ radu višu vrednosat aritmetičke sredine imaju nastavnici koji primenjuju elemente Programa „Korak po korak” u odnosu na nastavnike koji ove elemente ne primenjuju. Taj afektivni efekat odgovara ISSA pedagoškom standardu iz oblasti Strategije poučavanja - standard 5.4, pokazatelj 1: Učitelj modeluje i primenjuje procese i procedure kojima učenike podstiče na smislenu saradnju i međusobnu podršku. Statistička značajnost razlika u proceni nastavnika nastala je verovatno usled zasnovanosti Programa „Korak po korak” na demokratskim principima međusobnog uvažavanja i saradnje i organizacije procesa sticanja znanja u timskom radu.

U proceni afektivnog efekta ISSA pedagoških standarda iz oblasti Okruženje za učenje - standard 6.1, pokazatelj 1: Učitelj stvara okruženje koje obezbeđuje da se svaki učenik oseća prijatno $i$ da ima osećaj pripadanja, analiza prosečnih vrednosti procene za tvrdnju Ja osećam da pripadam svom odeljenju i tu mi je dobro pokazuje da višu prosečnu vrednost imaju učenici koji se ne školuju po elementima Programa „Korak po korak" (druga grupa) u odnosu na učenike koji se školuju po elementima ovog programa (prva grupa). Objašnjenje za dobijeni rezultat možda je u uzorku nastavnika koji ne primenjuju elemente Programa „Korak po korak", a koji, prema mišljenju učenika, očigledno kreiraju pozitivnu klimu u odeljenju i prijateljski ambijent. Procena tog afektivnog efekta može se povezati sa procenom socijalnog efekta Toleratno je na razlike, gde višu prosečnu vrednost procene imaju roditelji čija deca ne pohađaju odeljenja u kojima se primenjuju elementi Programa „Korak po korak” (druga grupa) u odnosu na roditelje čija deca pohađaju odeljenja u kojima se primenjuju elementi ovog programa (prva grupa).

Kada je reč o afektivnom efektu ISSA pedagoških standarda iz oblasti Interakcija - standard 1.2, pokazatelj 2: Učitelj nudi aktivnosti u kojima učenici uče da razlikuju i prepoznaju vlastite emocije, emocije drugih i da razgovaraju o njima i učenici i roditelji iz prve grupe saglasni su u proceni za tvrdnju Prepoznajem emocije kod sebe i drugih/Moje dete prepoznaje emocije kod sebe i drugih. Pri tome, značajno više prosečne vrednosti imaju učenici i roditelji iz prve grupe u odnosu na učenike i roditelje iz druge grupe. Razlog tome može se naći u specifičnosti metodologije Programa „Korak po korak”, koji podrazumeva kreiranje 
pozitivne atmosfere koja, između ostalog, podrazumeva i atmosferu zasnovanu na poverenju, međusobnom uvažavanju i osećanju pripadnosti u kojem emocije imaju veoma značajnu ulogu.

U proceni afektivnog efekta ISSA pedagoških standarda iz oblasti Strategije poučavanja-standard 5.1, pokazatelj 4: Učitelj prepoznaje, ceni $i$ kreira raznovrsne prilike za neformalno učenje izvan vremena predviđenog za neposredno poučavanje, analiza prosečnih vrednosti procene za tvrdnju Zainteresovano je za učestvovanje u raznim aktivnostima izvan škole (lokalne i zajedničke akcije, manifestacije u gradu, posete i sl) pokazuje da višu prosečnu vrednost imaju roditelji čija deca ne pohađaju odeljenja u kojima se primenjuju elementi Programa „Korak po korak” (druga grupa) u odnosu na roditelje čija deca pohađaju odeljenja u kojima se primenjuju elementi ovog programa (prva grupa). Razlog dobijenih razlika verovatno je u tome što nastavnici koji ne primenjuju elemente Programa „Korak po korak" (druga grupa) u većoj meri motivišu učenike za vanškolske aktivnosti ili ih uključuju u različite aktivnosti izvan škole. Dobijene razlike mogu da se protumače i kao rezultat kreativnog rada timova unutar škole.

U proceni afektivnog efekta ISSA pedagoških standarda iz oblasti Okruženje za učenje - standard 6.2, pokazatelj 4: Učitelj nudi bogat $i$ raznovrstan izbor dostupnih i razvojno-primerenih materijala koji učenike podstiču na istraživanje, igru i učenje, analiza prosečnih vrednosti procene za tvrdnju Volim da istražujem i eksperimentišem pokazuje da značajno višu prosečnu vrednost imaju učenici koji se školuju po elementima Programa „Korak po korak” u odnosu na učenike koji se ne školuju po elementima ovog programa. Objašnjenje dobijenog rezultata može se naći u činjenici da nastava usmerena na učenike pretpostavlja kreiranje nastavnih situacija i aktivnosti učenja koje omogućavaju učenicima da iskuse bogatstvo sveta kroz istraživanje i eksperimentisanje, te koje osposobljavaju učenike da postavljaju pitanja i tragaju za odgovorima.

Interpersonalni odnosi među učenicima - Druga studija sprovedena je radi ispitivanja interpersonalnih odnosa među učenicima, te učestalosti/ intenziteta interpersonalnih odnosa unutar odeljenja u kojima se primenjuju elementi Programa „Korak po korak” (prva grupa) i odeljenja u kojima se elementi ovog programa ne primenjuju (druga grupa). Prikazani rezultati u Tabeli 5. pokazuju da učenici iz prve grupe imaju više pozitivnih izbora u odnosu na učenike iz druge grupe, i da ta razlika u učestalosti pozitivnih izbora iznosi 0.52 . Takođe, rezultati pokazuju da učenici iz prve grupe 
imaju manje negativnih izbora u odnosu na učenike iz druge grupe, i da je ta razlika u učestalosti negativnih izbora -0.32 .

Tabela 5. Učestalost izbora na ukupnom uzorku učenika

\begin{tabular}{|c|c|c|c|c|c|}
\hline Grupa & $\begin{array}{l}\text { Broj } \\
\text { učenika }\end{array}$ & $\begin{array}{l}\text { Broj } \\
\text { pozitivnih } \\
\text { izbora }\end{array}$ & $\begin{array}{l}\text { Broj } \\
\text { pozitivnih } \\
\text { izbora po } \\
\text { učeniku }\end{array}$ & $\begin{array}{l}\text { Broj } \\
\text { negativnih } \\
\text { izbora }\end{array}$ & $\begin{array}{l}\text { Broj } \\
\text { negativnih } \\
\text { izbora po } \\
\text { učeniku }\end{array}$ \\
\hline Prva grupa & 397 & 1292 & 3.25 & 556 & 1.40 \\
\hline Druga grupa & 391 & 1070 & 2.74 & 672 & 1.72 \\
\hline $\begin{array}{l}\text { Razlika prve i } \\
\text { druge grupe }\end{array}$ & & 222 & 0.52 & -116 & -0.32 \\
\hline
\end{tabular}

Nakon kvantitativne, izvršena je i kvalitativna analiza, tj. ispitivani su razlozi pozitivnih izbora učenika. Odgovori učenika grupisani su u devet kategorija: 1. Dobar, dobar prema meni; 2. Lepo se igra, poštuje pravila igre; 3. Pomaže mi; 4. Radimo zajedno; 5. Duhovit, zabavan, šaljiv; 6. Poverenje, čuvanje tajni; 7. Iskrenost; 8. Volimo iste stvari, dobro se razumemo, slažemo se i 9. Ostalo (Drug iz vrtića, Zaljubljen, Treniramo zajedno, Pričamo). Na osnovu ranga koji je najčešće pripisivan određenim kategorijama, dobijena je rang-lista na kojoj se uočava da su rangovi obe grupe učenika podjednaki za prvo (Dobar, dobar prema meni), treće (Radimo zajedno), šesto (Duhovit, zabavan, šaljiv), sedmo (Poverenje, čuvanje tajni) i deveto (Ostalo) mesto. Razlike među ispitanicima prve i druge grupe postoje u rangiranju drugog, četvrtog, petog i osmog mesta.

Učenici iz prve grupe rangiraju na drugo mesto da im drugovi i drugarice iz odeljenja pomažu, što je od strane učenika iz druge grupe rangirano na peto mesto. Ako se dobijeni rezultati učenika iz prve grupe uporede sa procenom socijalnih efekata, uočava se da nastavnici i roditelji iz prve grupe, u odnosu na nastavnike i roditelje iz druge grupe, imaju značajno veće prosečne aritmetičke vrednosti za tvrdnju koja se odnosi na sposobnost učenika da rade u timu. Objašnjenje dobijenih razlika verovatno proizilazi iz metodologije Programa „Korak po korak”, koji pretpostavlja modelovanje aktivnosti učenja u okviru kojih se učestalo primenjuje timski rad, što ima kao posledicu da učenici jedni druge bolje i češće podržavaju nego što je to slučaj u odeljenjima u kojima se ne primenjuju elementi Programa „Korak po korak”. 
Učenici iz prve grupe rangiraju na četvrto mesto iskrenost drugova i drugarica, što je od strane učenika iz druge grupe rangirano na osmo mesto. U skladu sa dobijenim rezultatima učenika jeste i procena socijalnih efekata za tvrdnje Slobodno kažem svoje mišljenje i Prepoznajem emocije kod sebe $i$ drugih, gde učenici iz prve grupe imaju značajno veće prosečne vrednosti u odnosu na učenike iz druge grupe. Takođe, analiza prosečnih vrednosti procene za tvrdnju Moje dete prepoznaje emocije kod sebe $i$ drugih pokazuje da višu prosečnu vrednost imaju roditelji iz prve grupe u odnosu na roditelje iz druge grupe. Dobijene razlike mogle bi biti posledica metodologije Programa „Korak po korak” koji podrazumeva kreiranje pozitivne atmosfere u kojoj se nesmetano ostvaruje pun razvoj ličnosti svakog deteta. Pozitivna atmosfera, između ostalog, podrazumeva bezbednu sredinu zasnovanu na iskrenosti i poverenju, međusobnom uvažavanju i slobodnom iznošenju stavova.

Učenici koji se ne školuju prema elementima Programa „Korak po korak" (druga grupa) rangiraju na drugo mesto kategoriju Lepo se igra, poštuje pravila igre, kategoriju koja je od strane učenika koji se školuju prema elementima Programa „Korak po korak” (prva grupa) rangirana na peto mesto. Dobijeni rezultat može se dovesti u vezu sa procenom socijalnih efekata za tvrdnju Ponašam se po pravilima ponašanja, gde učenici iz druge grupe u odnosu na učenike iz prve grupe imaju višu vrednost aritmetičke sredine. Osim toga, učenici iz druge grupe rangiraju na drugo mesto kategoriju Volimo iste stvari, dobro se razumemo, slažemo se, dok je kod učenika iz prve grupe ova kategorija rangirana na osmo mesto.

\section{Zaključak}

Ključna ideja i opredeljenost za istraživanje inspirisana je aktuelnošću potrebe za ispitivanjem efekata metodologija usmerenih na učenika, konkretno na socijalnim i afektivnim efektima Programa „Korak po korak". Dobijeni rezultati pokazuju da nastavnici koji primenjuju elemente Programa „Korak po korak” imaju statistički značajno višu vrednost aritmatičke sredine na tvrdnjama koje se odnose na socijalne efekte u odnosu na nastavnike koji ovaj program ne primenjuju. Sociometrijskim ispitivanjem potvrđeno je da su pozitivni izbori učenika učestaliji, a negativni izbori manje učestali u odeljenjima u kojima se primenjuju elementi Programa „Korak po korak” u odnosu na odeljenja u kojima se 
elementi ovog programa ne primenjuju. Pri tome, dobijeni podaci za ukupan skor procene socijalnih efekata pokazuju da razlika između roditelja i učenika u odeljenjima u kojima se primenjuju elementi Programa „Korak po korak" i roditelja i učenika u odeljenjima u kojima se ne primenjuju elementi ovog programa nije statistički značajna. Takođe, nije utvrđena statistički značajna razlika u proceni afektivnih efekata između nastavnika, roditelja i učenika u odeljenjima u kojima se primenjuju elementi Programa „Korak po korak” i nastavnika, roditelja i učenika u odeljenjima u kojima se ne primenjuju elementi ovog programa. Ovakvi rezultati mogli bi biti posledica činjenice da su nastavnici u Republici Srbiji poslednjih nekoliko godina prošli mnogobrojne obuke koje su im ojačale kompetencije za rad u domenu socijalnog i afektivnog.

U celini posmatrano, moglo bi se zaključiti da dobijeni rezultati potvrđuju naučnu opravdanost primene metodologija usmerenih na dete, kakav je i Program „Korak po korak”. Implikacije ovog istraživanja mogu se posmatrati na makro nivou (republika, pokrajina, lokalna zajednica) i na mikro nivou (škola, odeljenja) obrazovanja i vaspitanja u Srbiji. Implikacije se na makro nivou prevashodno odnose na: promene u kurikulumima obrazovanja nastavnika razredne nastave; promene u stručnom usavršavanju nastavnika na akreditovanim programima za primenu metodologija usmerenih na dete; promovisanje metodologija usmerenih na dete na stručnim skupovima, konferencijama i drugim stručnim okupljanjima prosvetnih radnika; sprovođenje procedura za sticanje zvanja nastavnika koji realizuju nastavu usmerenu na dete; obezbeđivanje materijalnih sredstava i resursa za primenu programa usmerenih na dete koji zahtevaju veće prostorne uslove, odgovarajući didaktički materijal, nastavna sredstva i drugi potrošni materijal; obezbeđivanje sredstava za promovisanje primera dobre prakse i drugo. Na mikro nivou rezultati sprovedenog istraživanja mogu koristiti nastavnicima u sagledavanju vlastite prakse, te mogu biti značajni za izradu planova njihovog stručnog usavršavanja. 


\section{SOCIAL AND AFFECTIVE EFFECTS OF THE 'STEP-BY- STEP' PROGRAM APPLICATION}

\section{SUMMARY}

Abstract: Key ideas and commitment to the research emerge from the topicality of a need to examine the effects of methodologies aimed at pupils. The aim of the research is to determine the attitudes and opinions of teachers, parents, and pupils about the social and affective effects of the application of the "Step by Step" program elements in the Republic of Serbia, as well as to examine interpersonal relationships among the pupils, which are indicators of social and affective effects of teaching. Given the complexity of the set research objective, results and discussion are presented in two studies: the first study relates to the assessment of teachers, parents, and elementary school pupils on social and affective effects of teaching. The sample includes 1,617 respondents. Another study has been conducted to determine the interpersonal relationships among pupils, and the sample includes 788 elementary school pupils. Applied instruments are a questionnaire in the Likert-scale form of social and affective effects of teaching, and sociometric questionnaire.

The obtained results show that teachers who apply the elements of the "Step by Step" program have more statistically significant arithmetic mean for the claims relating to the social effects in comparison to the teachers who do not apply this program. Sociometric examination confirms that positive choices of pupils are more frequent, and negative choices are less frequent in classes where applicable elements of the program "Step by Step" in relation to the classes which do not apply the elements of this program. The conclusion is that the obtained results confirm the validity of applying scientific methodology aimed at children, such as the "Step by Step" program. The implications of this research could be viewed both at the macro level (the Republic, Province, local community) and the micro level (schools, departments) of education in Serbia.

Key words: a pupil-targeted teaching, 'Step-by-Step', teachers, parents, pupils. 


\section{Literatura}

Burke Walsh, K. (2003). Kreiranje vaspitno-obrazovnog procesa u kome dete ima centralnu ulogu - drugi i treći razred. Beograd: Centar za interaktivnu pedagogiju.

Burke Walsh, K. (2003). Stvaranje sredine za učenje usmerene na dete prvi razred. Beograd: Centar za interaktivnu pedagogiju.

Centar za evaluaciju, testiranje i istraživanje - CETI (2006). Evaluacija programa „Korak po Korak” program za decu i porodice-stvaranje učionica i obrazovne prakse u kojoj dete ima centralnu ulogu od I do IV razreda. Beograd: Centar za interaktivnu pedagogiju.

Klaus. S. \& Ghent, L. (2014). First Steps: A Brief History of the Step by Step Program. Retrieved April 17, 2013 from the World Wide Web https://www.opensocietyfoundations.org/voices/first-steps-briefhistory-step-step-program

Milić, S. (2008). Savremeni obrazovni sistemi. Podgorica: Univerzitet Crne Gore.

Milutinović, J. (2005). Konstruktivizam, konstrukcija znanja i promene u obrazovanju. Zbornik Odseka za pedagogiju, 22(19), 19-34.

Milutinović, J. (2011). Alternative u teoriji $i$ praksi savremenog obrazovanja: put ka kvalitetnom obrazovanju. Novi Sad: Savez pedagoških društava Vojvodine; Vršac: Visoka škola strukovnih studija za obrazovanje vaspitača „Mihailo Palov”.

Strategija razvoja obrazovanja u Srbiji do 2020. godine (2012). Službeni glasnik Republike Srbije - Prosvetni glasnik, Br. 107/2012. 